\title{
Development and reproductive performance of Hereford heifers of different frame sizes up to mating at 14-15 months of age
}

\author{
Maurício Dallmann da Silva ${ }^{1}$, José Fernando Piva Lobato ${ }^{2}$, Ricardo Zambarda Vaz ${ }^{3}$, Lidiane \\ Raquel Eloy ${ }^{1}$, Márcia Bitencourt Vaz ${ }^{4}$
}

\footnotetext{
${ }^{1}$ Universidade Federal do Rio Grande do Sul, Programa de Pós-graduação em Zootecnia, Porto Alegre, RS, Brazil.

2 Universidade Federal do Rio Grande do Sul, Faculdade de Agronomia, Departamento de Zootecnia, Porto Alegre, RS, Brazil.

${ }^{3}$ Universidade Federal de Pelotas, Faculdade de Agronomia Eliseu Maciel, Departamento de Zootecnia, Pelotas, RS, Brazil.

${ }^{4}$ Universidade Federal de Pelotas, Programa de Pós-graduação em Zootecnia, Pelotas, RS, Brazil.
}

\begin{abstract}
Body development and reproductive performance of a hundred forty-two 14 to 15 -month-old heifers, classified at weaning according to frame size as small, medium, and large, were evaluated. The parameters evaluated were: body weight, hip height, body condition score, weight gain, ovarian activity, and pregnancy rate. At weaning, body weight and hip height were significantly different among frame scores, (small - 133.0 kg, $92.2 \mathrm{~cm}$; medium - $158.5 \mathrm{~kg}, 96.6 \mathrm{~cm}$; and large $-185.2 \mathrm{~kg} ; 100.2 \mathrm{~cm}$ ). After weaning, heifers grazed together on natural pastures during the autumn and on ryegrass (Lolium multiflorum La.) during the winter and spring. Frame score differences remained until the beginning of the breeding season (BS), starting on average at 14 months of age. Weight gain between weaning and the beginning of BS was not different among frame scores $(0.740 \mathrm{~kg} /$ day, on average). Body weights at the beginning of the BS were significantly different, of $255.7 \mathrm{~kg}$ (53.3\% of the mature weight) for small heifers, $285.0 \mathrm{~kg}(59.4 \%)$ for medium heifers, and $307.6 \mathrm{~kg}(64.1 \%)$ for large heifers. Ovarian activity at the beginning of the BS was not different among the three groups. The average weight gain values during the BS of $0.492,0.472$, and $0.421 \mathrm{~kg}$ /day for small, medium, and large heifers, respectively, were significantly different. Pregnancy rates were not different among groups (small, 71.4\%; medium, 76.4\%; and large, 76.5\%). Frame score did not influence the reproductive performance of heifers, but the small and medium heifers conceived 29 and 20 days earlier, respectively, than the large heifers.
\end{abstract}

Key Words: age at conception, average daily gain, body condition score, hip height, ovarian activity, pregnancy rate

\section{Introduction}

The productivity of breeding-to-finish beef production systems is determined by the combination of three factors: reproductive efficiency of breeding herds, heifer age at first mating, and steer market age (Beretta et al., 2001). Performance indexes are influenced by production systems, which depend on the available production factors. Aiming at achieving higher efficiency and productivity and at complying with beef quality demands, the entire beef production chain - from the farmer to the packing plants - has sought to identify, among other factors that affect the production system, the best type of animal for each production environment.

Received: January 31, 2017

Accepted: September 18, 2017

*Corresponding author: jose.fernando.lobato@ufrgs.br

Copyright (C) 2018 Sociedade Brasileira de Zootecnia. This is an Open Access article distributed under the terms of the Creative Commons Attribution License (http://creativecommons.org/licenses/by/4.0/), which permits unrestricted use, distribution, and reproduction in any medium, provided the original work is properly cited.
In the so-called extensive production systems, in which cattle graze on natural or cultivated pastures and, therefore, may be subjected to nutritional and environmental restrictions, body size should be taken into account and has been studied since some years ago (Morris and Wilton, 1976). Body size is represented by the frame score, which is a convenient measure that relates hip height with body weight and age. Frame scores may be used to estimate growth rate and mature size, performance potential, and the nutritional requirements of an animal (BIF, 2010).

Body size influences breeding parameters, such as age and weight at puberty and pregnancy rates, as well as performance traits, including weaning weight, weight gain, mature weight, and carcass composition (NRC, 1996; Barbosa, 2006). For instance, large cows may be older at puberty and, consequently, present lower fertility rates than smaller cows in the same herd (Buttram and Willham, 1989; Olson, 1994).

Considering the diverse environments where beef cattle are produced in Brazil, particularly in terms of soil and climate, it is not possible to assign a single optimal 
animal size for all production systems. On the one hand, feedlot systems using grain feeding allow the production of large steers. On the other hand, the expansion of crops to pasture areas has pushed breeding heifers and cows to poorer pastures with low carrying capacity (Funston and Larson, 2011). In addition, under climates that further limit the nutritional value of the available pastures, smaller and early-maturing animals, with low nutritional requirements, may be required (Klosterman, 1972).

The objective of this study was to evaluate the development of heifers of three different sizes from weaning to mating at 14-15 months of age on a grazing system typical of the Pampa Biome of the state of Rio Grande do Sul, Brazil, without the use of any supplements.

\section{Material and Methods}

The protocol and conduction of these study were approved by the Research Ethics Committee of the Institution of Origin.

The experiment was conducted on a farm located in the municipality of Bage, physiographic region of Campanha, in the southwest of the state of Rio Grande do Sul, Brazil $\left(31^{\circ} 22^{\prime} \mathrm{S}\right.$ and $\left.54^{\circ} 39^{\prime} \mathrm{W}\right)$.

At weaning, 142 Hereford heifers born in the spring (September), with $228 \pm 8.7$ days old on average, were selected from the commercial breeding herd of the farm. All heifers were subjected to the same management practices and environment from birth to weaning. The effect of cow age on milk production was minimized by the distribution of heifers among the treatments (frame score or size).

Heifers were classified into one of the three groups: 1,2 , and 3 to frame score, according to the calculation of the Beef Improvement Federation (BIF, 2010), which considers age at weaning (days), hip height, and cow age. Groups 1, 2, and 3 are referred here as small, medium, and large, respectively.

During weaning, the calves were kept in a barn for 10 days. After weaning, heifers were managed as a unique group on natural pastures until June and then under rotational grazing until early December, in an area of 50 ha divided into four paddocks with annual ryegrass
(Lolium multiflorum Lam). The average stocking rate was 2.0 animal units $(\mathrm{AU}) / \mathrm{ha}(1 \mathrm{AU}=450 \mathrm{~kg})$, with pasture availability of 2,400 and $800 \mathrm{~kg} \mathrm{DM} / \mathrm{ha}$, corresponding to 25 and $8-10 \mathrm{~cm}$ pasture height, at the time animals entered and were removed from the pasture, respectively (Aguinaga et al., 2006). In December and afterwards, heifers were grazed on ryegrass stubble, the unique possibility in that year.

Heifers were weighed, after $12 \mathrm{~h}$ of feed and water fasting, at weaning and at the beginning and end of the breeding season of 61 days, and every 28 days between these periods. Daily weight gain was determined as the difference between weights divided by the number of days in each period. At the same dates, hip height (Dolezal and Coe, 1996) was measured and body condition was visually scored (Lowman et al., 1976) according to a 1-5 scale, in which 1 indicates a very thin animal, with easily visible ribs and hip bones and 5, a very fat animal, with evenly distributed fat cover.

On the dates animals were weighed, pasture samples were collected to determine the chemical composition (Table 1). Forage availability was estimated by the method described by t'Mannetje (2000). Pasture samples were dried in a forced-ventilation oven at $60^{\circ} \mathrm{C}$ for three days and then the dry matter, crude protein, and acid and neutral detergent fiber contents (AOAC, 1984) were determined.

Reproductive performance under natural mating was determined by the presence or absence of ovarian activity by ultrasound examination at the beginning of the breeding season and by pregnancy rate at 45 days after the end of breeding season. A $4 \%$ ratio of bulls approved by andrological examination was used.

Data of weight gain from birth to weaning were subjected to analysis of variance and used to the distribution of female calves in the three different groups. A completely randomized experimental design, with different number of replicates was applied, with repeated measures. Data were subjected to analysis of variance and to the F test, according to the following model:

$$
\mathrm{Y}_{\text {hij }}=\mu+\mathrm{F}_{\mathrm{i}}+\mathrm{HA}_{\mathrm{j}} \Sigma_{\text {hij }}
$$

in which $\mathrm{Y}_{\text {hij }}=$ dependent variable associated to the $h$-th animal; $\mu=$ mean of all observations; $F_{i}=$ fixed effect of

Table 1 - Chemical analysis of the pasture grazed during the experimental period

\begin{tabular}{|c|c|c|c|c|c|c|c|c|}
\hline Characteristic & June & July & August & September & October & November & December & January \\
\hline Dry matter (DM; \%) & 13.6 & 15.4 & 17.1 & 17.6 & 17.9 & 18.6 & 24.0 & 91.9 \\
\hline Availability (kg DM/ha) & 2230 & 2120 & 2380 & 2860 & 3200 & 2910 & 2870 & 2670 \\
\hline Crude protein $(\%)$ & 26.9 & 24.8 & 20.1 & 21.9 & 19.4 & 20.8 & 9.8 & 4.5 \\
\hline Neutral detergent fiber $(\%)$ & 48.7 & 50.6 & 48.3 & 49.1 & 54.1 & 57.1 & 59.0 & 82.0 \\
\hline Acid detergent fiber $(\%)$ & 23.8 & 24.3 & 21.2 & 22.6 & 27.1 & 29.7 & 30.2 & 49.0 \\
\hline Total digestible nutrients (\%) & 54.6 & 57.1 & 59.3 & 64.5 & 65.0 & 62.3 & 62.3 & 51.1 \\
\hline
\end{tabular}


the $i$-th frame; $\mathrm{HA}=$ heifer age covariate; and $\Sigma_{\mathrm{hij}}=$ random residual effect. The data were subjected to analysis of variance at the $5 \%$ level of significance through PROC MIXED of the SAS (Statistical Analysis System, version 9.4). When differences were detected, the means were compared by the $t$ test, at the $5 \%$ level of significance. The pregnancy rate was analyzed by the Chi-square test (Gomez and Gomez, 1984). The pregnancy rate data were subjected to cubic regression analysis, in relation to body weight at the beginning of the breeding season.

\section{Results}

Frame score was significantly affected by average birth weight, weight gain from birth to weaning, weaning weight, and height (Table 2). Large heifers were heavier at birth $(\mathrm{P}<0.05)$ than the medium and small heifers, which presented similar birth weight $(\mathrm{P}>0.05)$.

Analyses from birth to weaning showed that weight gain was associated with frame score. Although no differences in average age at weaning were detected, preweaning weight gain was significantly different $(\mathrm{P}<0.05)$ among frame groups, resulting in significant weaning weight differences $(\mathrm{P}<0.05)$ among small $(133.0 \mathrm{~kg})$, medium $(158.5 \mathrm{~kg})$, and large $(185.2 \mathrm{~kg})$ heifers.
Hip height was different among frame groups at weaning $(\mathrm{P}<0.05)$ (Table 2), with small, medium, and large heifers presenting 92.2, 96.6, and $100.2 \mathrm{~cm}$, respectively. These significant differences in height were maintained until the beginning of the breeding season and increased in $16.8,15.7$, and $15.4 \%$ for the small, medium, and large heifers, respectively.

Body weight to hip height ratio was also significantly different among groups and proportional to frame (Table 2).

From weaning to the beginning of the breeding season, the three groups presented similar weight gain $(\mathrm{P}>0.05)$, with values of $0.753,0.747$, and $0.783 \mathrm{~kg}$ /day for small, medium, and large heifers, respectively. However, their body weights at the beginning of the breeding season were different $(\mathrm{P}<0.05)$ due to weight gain differences until weaning (Table 3 ).

The weight gain and hip height differences observed at weaning were maintained in the beginning and in the end of the breeding season $(\mathrm{P}<0.05)$ (Table 3 ).

At the beginning of the breeding season, small, medium, and large heifers presented the means of body weight of 255.7, 285.0, and $307.6 \mathrm{~kg}(\mathrm{P}<0.05)$. Body condition score was also significantly different $(\mathrm{P}<0.05)$ among frame groups and increased with frame (Table 3 ).

Table 2 - Heifer body development parameters at weaning according to frame group

\begin{tabular}{|c|c|c|c|}
\hline Parameter & Small & Medium & Large \\
\hline Number of calves per group & 46 & 48 & 48 \\
\hline Birth weight $(\mathrm{kg})$ & $32.2 \pm 0.65 b$ & $32.5 \pm 0.64 b$ & $34.9 \pm 0.63 \mathrm{a}$ \\
\hline Age at weaning (days) & $231 \pm 7$ & $226 \pm 6$ & $227 \pm 6$ \\
\hline Weight gain (birth-weaning; kg) & $0.449 \pm 0.008 \mathrm{c}$ & $0.560 \pm 0.008 b$ & $0.667 \pm 0.008 \mathrm{a}$ \\
\hline Weaning weight $(\mathrm{kg})$ & $133.0 \pm 1.70 \mathrm{c}$ & $158.5 \pm 1.72 b$ & $185.2 \pm 1.69 \mathrm{a}$ \\
\hline Hip height at weaning $(\mathrm{cm})$ & $92.2 \pm 0.44 \mathrm{c}$ & $96.6 \pm 0.44 b$ & $100.2 \pm 0.43 \mathrm{a}$ \\
\hline Frame score $(1-9)^{1}$ & 1 & 2 & 3 \\
\hline Body weight:hip height ratio $(\mathrm{kg} / \mathrm{cm})$ & $1.44 \pm 0.22 \mathrm{c}$ & $1.64 \pm 0.24 b$ & $1.85 \pm 0.25 \mathrm{a}$ \\
\hline
\end{tabular}

a,b - Different lowercase letters in the same row are different by the $t$ test $(\mathrm{P}<0.05)$.

${ }^{1}$ Scale of the Beef Improvement Federation (BIF, 2010).

Table 3 - Mean and standard deviation of heifer body development parameters according to frame group from weaning to the end the breeding season according to frame group

\begin{tabular}{|c|c|c|c|}
\hline Parameter & Small & Medium & Large \\
\hline Weight gain (weaning-breeding; kg) & $0.726 \pm 0.014$ & $0.744 \pm 0.014$ & $0.749 \pm 0.014$ \\
\hline Body weight at the beginning of the breeding season $(\mathrm{kg})$ & $255.7 \pm 2.6 \mathrm{c}$ & $285.0 \pm 2.56 b$ & $307.6 \pm 2.54 \mathrm{a}$ \\
\hline Body weight at the end of the breeding season $(\mathrm{kg})$ & $289.4 \pm 3.3 \mathrm{c}$ & $318.5 \pm 3.3 b$ & $338.8 \pm 3.2 \mathrm{a}$ \\
\hline Daily weight gain during the breeding season $(\mathrm{kg})$ & $0.552 \pm 0.027$ & $0.549 \pm 0.028$ & $0.511 \pm 0.028$ \\
\hline Hip height at the beginning of the breeding season $(\mathrm{cm})$ & $107.7 \pm 0.39 \mathrm{c}$ & $111.8 \pm 0.39 \mathrm{~b}$ & $115.6 \pm 0.39 \mathrm{a}$ \\
\hline Body weight:hip height ratio at the beginning of the breeding season $(\mathrm{kg} / \mathrm{cm})$ & $2.37 \pm 0.02 \mathrm{c}$ & $2.55 \pm 0.02 b$ & $2.68 \pm 0.02 \mathrm{a}$ \\
\hline Body condition score at the beginning of the breeding season & $3.71 \pm 0.05 \mathrm{c}$ & $4.08 \pm 0.06 \mathrm{~b}$ & $4.28 \pm 0.06 \mathrm{a}$ \\
\hline Body condition score at the end of the breeding season & $3.88 \pm 0.04 \mathrm{~b}$ & $3.99 \pm 0.04 \mathrm{ab}$ & $4.07 \pm 0.04 \mathrm{a}$ \\
\hline Ovarian activity at 12 months of age $(\%)$ & 84.7 & 79.4 & 87.1 \\
\hline Pregnancy rate $(\%)$ & 71.4 & 76.4 & 76.5 \\
\hline Age at conception (days) & 419 & 427 & 448 \\
\hline
\end{tabular}

$\mathrm{a}, \mathrm{b}$ - Different lowercase letters in the same row are different by the $\mathrm{t}$ test $(\mathrm{P}<0.05)$. 
Ovarian activity at the beginning of the breeding season was not different among frame groups $(\mathrm{P}>0.05)$ and was $83.7 \%$, on average.

Daily body weight variation during the breeding season was similar among frame groups (Table 3) because of the low quality of the pasture (Table 1).

Despite not affecting daily body weight variation among the three groups during the breeding season, nutrient restriction influenced heifer visual body condition scores. The body condition score of large heifers was reduced (4.28 to 4.07) due to their higher nutritional requirements compared with the small heifers, which body condition score slightly increased (3.71 to 3.88 ) between the beginning and end of the breeding season. The body condition score of small heifers was significantly lower compared with the other two groups in the beginning of the breeding season, but reached statistically similar score as the medium heifers at the end of the breeding season.

Pregnancy rates of $71.4,76.4$, and $76.5 \%$ obtained by small, medium, and large heifers, respectively, were not different $(\mathrm{P}>0.05)$. The average age at conception of small, medium, and large heifers was 419, 427, and 448 days, respectively (Table 3), indicating that small and medium heifers conceived 29 and 21 days earlier than the large heifers.

Although heifer frame did not influence pregnancy rate, the pregnant heifers presented higher weight gain during the breeding season, as well as higher body weight and body condition score at the end of that season compared with the non-pregnant heifers. Pregnancy rate presented a cubic response to body weight: it increased up to $272 \mathrm{~kg}$ and was similar between 260 and $332 \mathrm{~kg}$ (Figure 1).

\section{Discussion}

The greater weight of large calves at weaning is due to the fact that they are more efficient at gaining weight up to

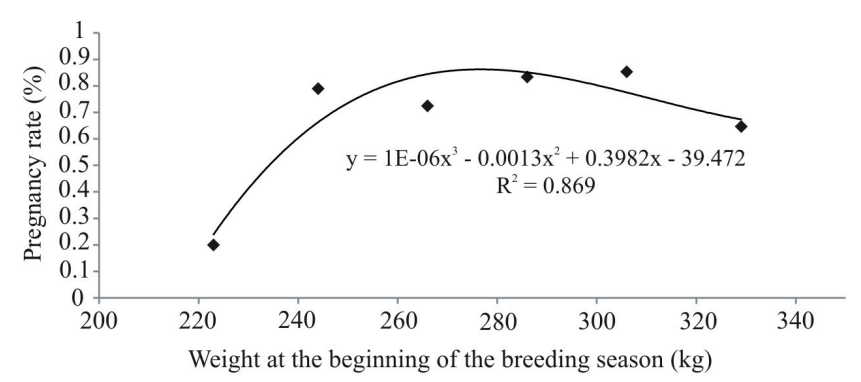

Figure 1 - Pregnancy rate as a function of weight at the beginning of the breeding season
$25 \%$ of their mature weight (Webster, 1989). Large cattle, independently of breed, are usually heavier at birth than medium and small cattle (Long et al., 1975; Vargas et al., 1999). The average birth weight obtained was $33.7 \mathrm{~kg}$, consistent with that reported for Hereford herds in the state of Rio Grande do Sul (Mazzini et al., 2003).

The analyses from birth to weaning indicate that this herd presented different weight gain potential until weaning (Thonney et al., 1981), possibly due to differences in dam milk production. Large animals are more efficient when environmental conditions and nutrition are not limiting (Cartwright et al., 1981; Di Marco, 1998), as in the case of the present study, when the dams and their calves grazed on ryegrass since the beginning of calving, mid-August, to the end of this pasture cycle, end November, when returned to graze on natural pastures.

High pre-weaning weight gain and, consequently, high weaning weight, are essential to obtain good pregnancy rates when heifers are mated at 14-15 months of age (Rocha and Lobato, 2002; Vaz et al., 2012), with influences on the reproduction performance when they are primiparous cows (Scaglia, 1997). Quadros and Lobato (1997) showed that calves born in the beginning of spring (September) from cows grazing on natural pastures at low stocking rates and, therefore, with high pasture allowance and better quality, are heavier at weaning.

Despite significant, the differences in hip height are small among the frames, possibly as a result of the selection of this commercial herd for larger frames during the last 40 years. Baker et al. (1988) considered that hip height is the most convenient way to describe the skeleton size in beef cattle. Although Pereira et al. (2010) found high positive correlations between growth traits and hip height, the authors concluded it had little influence on the reproductive performance of Nelore heifers. Those authors also found that hip height of heifers at weaning may be influenced by dam age. Hip height of heifers calved by three to four-yearold cows or older than 13 years is lower than those calved by 5 to 12 -year-old cows.

Body weight to hip height ratio was different among groups and proportional to frame and can be used to determine body condition score (Olson et al., 1982), as well as biotype differences (Klosterman et al., 1968; Montanholi et al., 2004), and is correlated with heifer growth rate (Costa et al., 2009).

Under challenging environmental and nutritional conditions, cattle with different frames may present similar growth rates, because the nutritional requirements of the large animals are not fully supplied (Thonney et al., 1981). 
Despite their potential for higher weight gain (Di Marco, 1998), the lack of differences in weight gain from weaning to breeding among frame sizes may be explained by the insufficient nutrient supply (NRC, 1996) to the large heifers due to the ryegrass offer during the grazing cycle and the poor quality of the ryegrass stubble on offer in December and specially in January (Table 1). The stubble on offer was extremely dry (91.9\%), had $4.5 \%$ of CP and $82.0 \%$ of neutral detergent fiber. Carvalho et al. (2011) demonstrated higher weight gain per area and per animal with a pasture height of $15-25 \mathrm{~cm}$ high and a uniform pasture allowance of $3000 \mathrm{~kg}$ of dry matter during the vegetative period, which was not the situation in the present study.

The obtained weight gains are compatible with the availability of dry matter and crude protein of the forage (Table 1). However, the low energy values obtained when the pasture started to be grazed, and particularly after the end of its vegetative cycle, were not sufficient to supply the requirements of heifers and, therefore, did not result in weight gain differences, as previously observed by Santos et al. (2005). Cattle grazing on cultivated pastures may present continuous weight gain during the pasture production cycle when energy-protein supplements are given, at the beginning of the cycle on protein-rich pastures (Pilau et al., 2004), and in the end of the cycle, when the pasture contains low crude protein and high neutral detergent fiber levels (Pilau et al., 2005). No supplement was prepared to be offered in such period in the present study. Recently, Gonzales (2015) showed that Brangus heifers with daily weight gains inferior to $0.357 \mathrm{~kg}$ reduce the fat cover, or the body condition score, measured monthly with more accuracy by ultrasonography.

The mean body weights of 255.7, 285.0, and $307.6 \mathrm{~kg}$, of small, medium, and large heifers at the beginning of the breeding season, which corresponded to 53.3, 59.4, and $64.1 \%$ of the mean of $480-\mathrm{kg}$ cow mature weight in a good body condition of this farm, are considered sufficient to allow breeding the medium and large heifers at 14 months of age. The NRC (1996) recommended 60\% to Bos taurus and $65 \%$ to Bos indicus heifers of their mature weight to reach puberty and conceive. Bolze and Corah (1993), however, recommended $65 \%$ of mature weight of Bos taurus heifers. By the end of the breeding season, the small heifers reached, on average, $64 \%$ of the mature weight, which, however, should have been achieved at the beginning of the season.

Larson et al. (2011) concluded that 55\% mature weight provides good reproduction results when beef heifers are maintained in uniform herds and under adequate nutritional systems, but not when there are nutritional limitations. The genetic selection of beef heifers for breeding at younger ages and, therefore, lower body weights at mating (Glasser, 2013; Hersom et al., 2013), determined lower nutritional requirements of these animals (Funston and Larson, 2011). Vaz and Lobato (2010) classified heifers weaned at 77 and 147 days of age in weight groups and found that $58.8 \%$ did not achieve the minimum weight of $275 \mathrm{~kg}$ at the beginning of the breeding season. However, out of that percentage, $53 \%$ conceived, demonstrating that target body weight at the beginning of the breeding season may not always be a limiting factor. As expressed by NRC (1996), numerous data are available that indicate that neither age nor weight is a reliable indicator of reproductive development, but that threshold values for both age and weight must be reached before puberty can occur.

This may also indicate that target weights may vary according to cattle type, which may be very heterogeneous in beef cattle herds, as has been happening in Brazilian beef herds recently. Nevertheless, several authors showed positive correlations between heifer target weight at mating and pregnancy rate (Wiltbank et al., 1985; Silva et al., 2005). Heifers weighing more than $65 \%$ of their mature weight, according to breed and type, present high pregnancy rates (Kroetz and Neves, 1985; DeRouen and Franke, 1989), which is an important productivity indicator of breedingto-finish systems (Beretta et al., 2001; Vieira et al. 2006).

Hip height is an important source of variation of the age (days) and body weight at puberty, but is less susceptible to environmental variations than body weight (Baker et al., 1981; Vargas et al., 1998).

At the beginning of the breeding season, heifers were, on average, $415 \pm 10.2$ days old. At this age, however, different weight to height ratios $(\mathrm{P}<0.05)$ were determined. The ratios were close to those recommended in literature, of 2.53 to $2.77 \mathrm{~kg} / \mathrm{cm}$ for frame of 1 to 9 (Fox et al., 1988). Costa et al. (2009), however, found that this ratio may vary in Hereford heifers as a function of the nutritional levels supplied between weaning and 15 months of age. At the end of the cycle, already in end December, and January, the ryegrass stubble presented poor quality, CP of $9.8 \%$ and $4.5 \%$, respectively, associated to the worst total digestible nutrients values in the same months, subtracted the possibility of expressing better results. Probably, the offering of a supplement as supported by Pilau and Lobato (2009) in this poor-quality period of the pasture on offer should give better answers.

Body condition score was significantly different among frame groups and higher in the large one, disagreeing with the literature, in which cattle with small biotypes deposit visible subcutaneous fat earlier than those with large 
biotypes (McCarthy et al., 1985). However, Sampedro (2003) suggested that this parameter has low correlation with the reproductive performance when heifers were 18 months old.

Ovarian activity was not different among frame groups at the beginning of the breeding season (Table 3), $83.7 \%$ on average, which is a reasonable cycling percentage to a herd having the first mating in this age. Replacement heifers should reach puberty approximately 60 days before the breeding season to conceive at the beginning of that season, as heifers mated in the third estrous cycle present better reproductive performance compared with those mated in the first two cycles (Byerley et al., 1987). The presence of ovarian activity before the breeding season is important because the first conception at the beginning of the season will determine higher future reproductive efficiency and herd productivity. Heifers that conceive late in the breeding season have lower productivity, their calves are lighter at weaning, and they present longer calving intervals compared with those that conceive at the beginning of that season (Lesmeister et al., 1973).

Pregnancy rates were not different among frame groups, $74.8 \%$ on average, probably as a result of pasture quality available, which affected more the large heifers. During the first 35 days of the mating period, there were no differences in weight gains (mean of $0.585 \mathrm{~kg} /$ day) among the three groups, but on the last 35 days, small, medium, and large heifers presented gain of $0.371,0.317$, and 0.244 $\mathrm{kg} /$ day $(\mathrm{P}<0.05)$, respectively. Under feed restriction, as observed with the quality of stubble available, small heifers gained more weight and were maybe more fertile than large heifers (Vargas et al., 1999), which may lead to similar reproductive performance (Olson et al., 1982). The low nutrient supply may be explained by the low forage quality at the end of the ryegrass growing cycle, the lack of another forage alternative at the time on the farm, and also by the extreme climate conditions observed during that period, which inhibited the possible regrowth of natural forage species. In that period, the region of the study experienced long and strong draught, with rainfall (56.5, 97.0, and $19.5 \mathrm{~mm}$, in November, December, and January, respectively) well below the normal levels (117, 122, and $124 \mathrm{~mm}$, respectively) (EMBRAPA, 2016) during the breeding season, without any rain between November 16 to December 17. In addition, the recorded average and range monthly temperatures (22 and 12 to $34 ; 23$ and 16 to $35 ; 23$ and 11 to $35{ }^{\circ} \mathrm{C}$, to November, December, and January, respectively) were much higher temperature than the historical averages in the studied region ( 21 and 17 to 26; 23 and 19 to $29 ; 25$ and 20 to $31^{\circ} \mathrm{C}$, respectively). Such environmental extremes may have caused embryo mortality and, therefore, reduced the pregnancy rates (Rocha et al., 2012). Environmental temperatures above the thermal comfort zone cause imbalances in estrogen/progesterone ratio, resulting in embryo death before implantation or embryo underdevelopment (Thatcher and Collier, 1982), as well as reduced uterine blood flow and increased uterine temperature, reducing embryo survival (Putney, 1989).

Despite satisfactory for a herd recently beginning the mating with 14-15 months old, higher pregnancy rates were expected considering the body weights and body condition scores determined in all three frame groups, which, on average, reached the target weight required for the onset of puberty and for conception until the end of the breeding season. Other authors, working with heifers of the same age and fed similar diets, obtained lower pregnancy rates than the present study; however, the body weights of their heifers at the start of breeding season were lower, also due to lower weaning weights (Rocha and Lobato, 2002; Pilau et al., 2005; Azambuja et al., 2008; Pilau and Lobato, 2009).

The average age at conception indicated that small and medium heifers conceived 29 and 21 days earlier than the large heifers. The averages were 419, 427, and 448 days, respectively, for small, medium, and large heifers. Olson et al. (1998) also classified heifers as small, medium, and large as a function of hip height and observed that large heifers were less productive and older at puberty compared with medium and small heifers, with similar weaning rates of 61.6 and $62.8 \%$ in the first and second parity. The later the heifer conceives, the lower is its pregnancy rate (Pötter and Lobato, 2004). First-calf heifers that conceive in the beginning of the breeding season, and therefore, that calve in the beginning of the calving season, present higher pregnancy rates (Osoro, 1986). In addition, a higher number of calvings in the beginning of the calving season allow for a longer interval between calving and the next breeding season (Vaz et al., 2010).

Regardless of the original frame classification (Table 4), pregnant heifers were heavier at the end of the breeding season due to their higher weight gain during mating compared with non-pregnant heifers $(\mathrm{P}<0.05)$. It has been previously shown that pregnant heifers present better growth rates and body condition scores than non-pregnant heifers (Semmellman et al., 2001; Rocha and Lobato, 2002). These responses allow the selection of heifers better adapted to each production system. In addition, when lighter female calves - which are also probably younger - are identified at weaning, they may be more intensively managed to supply them with better nutrition and weight 
Table 4 - Mean and standard deviation of body weight, body condition score, weight gain, and age of heifers diagnosed as pregnant or not

\begin{tabular}{lcc}
\hline & Pregnant & Not pregnant \\
\hline Small heifers (n) & 33 & 13 \\
Medium heifers (n) & 36 & 12 \\
Large heifers (n) & 37 & 11 \\
Body weight (kg) & $33.3 \pm 1.21$ & $33.0 \pm 1.13$ \\
$\quad$ Birth & $151.4 \pm 2.14$ & $146.9 \pm 3.84$ \\
Weaning & $285.3 \pm 2.79$ & $278.4 \pm 5.00$ \\
Beginning of the breeding season & $323.3 \pm 3.00$ & $310.8 \pm 5.39 *$ \\
End of the breeding season & & \\
Body condition score & $4.08 \pm 0.05$ & $3.90 \pm 0.09^{*}$ \\
Beginning of the breeding season & $4.02 \pm 0.05$ & $3.86 \pm 0.05^{*}$ \\
End of the breeding season & & \\
Average daily gain (kg/day) & $0.559 \pm 0.010$ & $0.559 \pm 0.018$ \\
Birth to weaning & $0.744 \pm 0.010$ & $0.730 \pm 0.017$ \\
Weaning to breeding & $0.623 \pm 0.018$ & $0.531 \pm 0.032^{*}$ \\
Beginning to end of the breeding season & $424 \pm 1.36$ & $427 \pm 2.38$ \\
Average age at mating (days) & & \\
\hline P $<0.05$. & &
\end{tabular}

gain to allow them to conceive at the same age as their contemporaries (Beretta and Lobato, 1998; Pereira Neto and Lobato, 1998).

Higher body weight gain in pregnant heifers compared with non-pregnant heifers is reported in the literature (Rocha and Lobato, 2002); Azambuja et al., 2008). Patterson et al. (1992) emphasized the importance of pre-weaning weight gain for puberty onset, considering the harmful effects of poor nutrition on puberty described by Short and Bellows (1971). In the study of Bittencourt et al. (2005), the body weight of 14 to 15 -month-old heifers in the beginning of the breeding season explained $73.6 \%$ of the variation in pregnancy probability and an optimal body weight of $338.8 \mathrm{~kg}$ was determined.

Pregnancy from heifers at 14-15 months of age is associated with their body weight (Vaz et al., 2010). However, Barcellos et al. (2006), when analyzing older heifers, between 18 and 24 months of age, did not detect any pregnancy rate increase after a given weight. Puberty onset in cattle is determined by animal age, body weight, and their interaction. Therefore, heifers must gain weight in a non-restrictive environment (Gregory et al., 1991; Restle et al., 1999).

The lack of significant body weight changes from birth to mating both in pregnant and non-pregnant heifers are consistent with the pregnancy rates obtained. It is possible that higher pregnancy rates could have been obtained if weight gains were higher and supplements were provided, specially in the period of 20-30 days prior the end of annual ryegrass cycle and the first 20-30 days or more, when grazing ryegrass stubble or, as usually, when returning to graze natural pasture in these months. In intensive systems, the assurance of more food is strongly necessary to get effective results, because it is impossible to be safe based only on pastures, improved or natural, and expected normal rainfall and temperatures. This was previously recommended by Pilau and Lobato (2009), based on the gains observed in heifers supplemented in this period. More intensive systems require the guarantee of extra food supply to avoid any unexpected hard climate effects, for which they were not prepared in this situation. The pregnancy rate differences as a function of heifer frame score obtained in the present study are smaller than those reported in literature. Other authors, despite working with larger frame differences, more advanced and intensive production systems, with better genetics and nutrient resources, did not find any reproductive performance differences because the nutritional requirements of all heifers were met (Cartwright et al., 1981; Olson et al., 1982).

\section{Conclusions}

The development of heifers of three different sizes from weaning to mating at 14-15 months of age does not affect pregnancy rates. Body condition score at the beginning and end of the breeding season and body weight gain affect conception rate, regardless of frame size. In more intensive grazing systems, higher pasture offer and quality or even food reserves are necessary to compensate for the climate uncertainty, to keep the weight gains based on the animal genetic potential.

\section{References}

Aguinaga, A. Q. A.; Carvalho, P. C. F.; Anghinoni, I.; Santos, D. T.; Freitas, F. K. and Lopes, M. T. 2006. Produção de novilhos superprecoces em pastagem de aveia e azevém submetida a diferentes alturas de manejo. Revista Brasileira de Zootecnia 35:1765-1773

AOAC - Association of Official Analytical Chemits. 1984. Official methods of analysis. 14th ed. AOAC Internacional. Washington, D.C.

Azambuja, P. S.; Pilau, A. and Lobato, J. F. P. 2008. Suplementação alimentar de novilhas no pós-desmame: efeitos no crescimento e desempenho reprodutivo. Revista Brasileira de Zootecnia 37:1042-1049.

Baker, J. F.; Stewart, T. S.; Long, C. R. and Cartwright, T. C. 1988. Multiple regression and principal components analysis of puberty and growth in cattle. Journal of Animal Science 66:2147-2158.

Baker, J. H.; Kropp, J. R.; Turman, E. J. and Buchanan, D. S. 1981. Growth rates and relationships among frame size, performance traits and scrotal circumference in young beef bulls. p.24-30. In: Animal Science Research Report, Oklahoma Agricultural Experiment Station, Oklahoma State University, Stillwater.

Barbosa, P. F. 2006. Tamanho da estrutura corporal e desempenho produtivo de bovinos de corte. p.718-740. In: Anais da $43^{\text {a }}$ Reunião 
da Sociedade Brasileira de Zootecnia. Sociedade Brasileira de Zootecnia, João Pessoa.

Barcellos, J. O. J.; Silva, M. D.; Prates, E. R. and Costa, E. C. D. 2006. Taxas de prenhez em novilhas de corte acasaladas aos 18 e 24 meses de idade. Arquivo Brasileiro de Medicina Veterinária e Zootecnia 58:1168-1173.

Beretta, V. and Lobato, J. F. P. 1998. Sistema "um ano" de produção de carne: avaliação de estratégias alternativas de alimentação hibernal de novilhas de reposição. Revista Brasileira de Zootecnia 27:157-163.

Beretta, V.; Lobato, J. F. P. and Mielitz Neto, C. G. 2001. Produtividade e eficiência biológica de sistemas pecuários de cria diferindo na idade das novilhas ao primeiro parto e na taxa de natalidade do rebanho no Rio Grande de Sul. Revista Brasileira de Zootecnia 30:1278-1286.

BIF - Beef Improvement Federation. 2010. Guidelines for uniform Beef Improvement Programs. 8th ed. Beef Improvement Federation and University of Georgia, Athens, GA.

Bittencourt, H. R.; Gottschall, C. S. and Sant'ana, M. F. 2005. Um modelo alternativo para a predição da probabilidade de prenhez em função do peso ao início do acasalamento. Arquivos de Ciências Veterinárias e Zoologia 8:99-104.

Bolze, R. and Corah, L. R. 1993. Selection and development of replacement heifers. Kansas State University, Cooperative Extension Service, Manhattan.

Buttram, S. T. and Willham, R. L. 1989. Size and management effects on reproduction in first- second- and third-parity beef cows. Journal of Animal Science 67:2191-2196.

Byerley, D. J.; Staimiller, R. B.; Berardinel, L. I. and Short, R. E. 1987. Pregnancy rates of beef heifers bred either on pubertal or third estrus. Journal of Animal Science 65:645-650.

Cartwright, T. C.; Stokes, K. W. and Stuth, J. W. 1981. Evaluation of effect of cow size and milk production on herd productivity in Central Texas. p.94-97. In: Beef Cattle Research in Texas.

Carvalho, P. C. F.; Anghinoni, I.; Kunrath, T. R.; Martins, A.; Costa, S. E. V. G. A.; Silva, F. D.; Assmann, J. M.; Lopes, M. L. T.; Pfeifer, F. M.; Conte, O. and Souza, E. D. 2011. Integração soja-bovinos de corte no Sul do Brasil. Boletim Técnico. UFRGS, Porto Alegre. Available at: <http://www.fao.org/fileadmin/templates/ agphome/documents/rangelands/Boletim T\%C3\%A9cnico_com Capa_01.pdf >. Accessed on: Dec. 14, 2014.

Costa, E. C.; Barcellos, J. O. J.; Peripolli, V.; Oliveira, T. E.; López, J. and Bracini Neto, J. 2009. Crescimento de novilhas de corte com diferentes ganhos de peso dos 12 aos 18 meses de idade. Acta Scientiae Veterinariae 37:125-132.

DeRouen, S. M. and Franke, D. E. 1989. Effects of sire breed, breed type and age and weight at breeding on calving rate and date in beef heifers first exposed at three ages. Journal of Animal Science 67:1128-1137.

Di Marco, O. N. 1998. Crecimiento de vacunos para carne. 2 ed. Mar Del Prata, República Argentina.

Dolezal, S. L. and Coe, E. 1996. Hip height and frame determination. p.17-20. In: Beef Improvement Federation (BIF) guidelines. 7th ed. North Carolina.

EMBRAPA - Empresa Brasileira de Pesquisa Agropecuária. 2016. Dados do Instituto Nacional de Meteorologia. Available at: $<\mathrm{http}: / /$ www.inmet.gov.br/sonabra/dspDadosCodigo.php?QTgyNw>. Accessed on: Nov. 30, 2016.

Fox, D. G.; Sniffen, C. J. and O'Connor, J. D. 1988. Adjusting nutrient requirements of beef cattle for animal and environmental variations. Journal of Animal Science 66:1475.

Funston, R. N. and Larson, D. M. 2011. Heifer development systems: Dry-lot feeding compared with grazing dormant winter forage. Journal of Animal Science 89:1595-1602.
Glasser, C. L. 2013. Joint Alpharma-Beef Species Symposium: Considerations on puberty in replacement beef heifer. Journal of Animal Science 91:1336-1340.

Gomez, K. A. and Gomez, A. A. 1984. Statistical procedures for agricultural research. 2nd ed. John Wiley and Sons, Inc. New York.

Gonzales, F. A. L. 2015. Crescimento e desenvolvimento de fêmeas Brangus. Dissertação (M.Sc.). Universidade Federal do Rio Grande do Sul, Porto Alegre.

Gregory, K. E.; Lunstra, D. D.; Cundiff, L. V. and Koch, R. M. 1991. Breed effects and heterosis in advanced generations of composite populations for puberty and scrotal traits of beef cattle. Journal Animal Science 69:2795-2807.

Hersom, M. J.; Bodine, T. and Herring, A. 2013. Joint Alpharma-Beef Species Symposium: Redefining the replacement heifer paradigm. Journal of Animal Science 91:1321-132.

Klosterman, E. W.; Sanford, L. G. and Parker, C. F. 1968. Effect of cow size and condition and ration protein content upon maintenance requirements of mature beef cows. Journal of Animal Science 27:242-246.

Klosterman, E. W. 1972. Beef cattle size for maximum efficiency. Journal of Animal Science 34:875-880.

Kroetz, I. A. and Neves, J. P. 1985. Influências do peso corporal na fecundidade de vacas e novilhas de corte. Revista do Centro Ciências Rurais 15:89-96.

Larson, D. M.; Cupp, A. S. and Funston, R. N. 2011. Heifer development systems: a comparison of grazing winter range or corn residue. Journal of Animal Science 89:2365-2372.

Lesmeister, J. L.; Burfening, P. J.; and Blackwell, R. L. 1973. Date of first calving in beef cows and subsequent calf production. Journal of Animal Science 36:1-6.

Long, C. R.; Cartwright, T. C. and Fitzhugh Jr., H. A. 1975. Systems analysis of sources of genetic and environmental variation in efficiency of beef production: cow size and management. Journal of Animal Science 40:409-420.

Lowman, B. G.; Scott, N. and Somerville, S. 1976. Condition scoring beef cattle. East of Scotland College of Agriculture, Edinburgh.

Mazzini, A. R. A.; Muniz, J. A.; Aquino, L. H. and Silva, F. F. 2003. Análise da curva de crescimento de machos Hereford. Ciência Agropecuária 27:1105-1112.

McCarthy, F. D.; Hawkins, D. R. and Bergen, W. D. 1985. Dietary energy density and frame size effects on composition of gain in feedlot cattle. Journal of Animal Science 60:781-790.

Montanholi, Y. R.; Barcellos, J. O. J.; Borges, J. B.; Costa, E. C.; Wunsh, C. and Prates, E. R. 2004. Ganho de peso na recria e desempenho reprodutivo de novilhas acasaladas com sobreano. Pesquisa Agropecuária Brasileira 39:1253-1259.

Morris, C. A. and Wilton, J. W. 1976. Influence of body size on the biological efficiency of cows. A review. Canadian Journal of Animal Science 56:613-647.

NRC - National Research Council. 1996. Nutrient requirement of beef cattle. National Academy Press, Washington, D.C.

Olson, L. W.; Peschel, D. E.; Paulson, W. H. and Rutledge, J. J. 1982. Effects of cow size on cow productivity and on calf growth, post weaning growth efficiency and carcass traits. Journal of Animal Science 54:704-712.

Olson, T.; Vargas, C. A.; Chase, C. C. and Hammond, A. C. 1998 Relación entre tamaño corporal y fertilidad en ganado brahman. p.35-45. In: Anais do I Congreso Internacional de Producción de Carne. APCN - Asunción.

Olson, T. A. 1994. The effect of cow size on reproduction. p.243-249. In: Factors affecting calf crop. Fields, M. J. and Sand, R. S., eds. CRC Press, London. 
Osoro, K. 1986. Efecto de las principales variables de manejo sobre los parámetros reproductivos en las vacas de cria. Investigación Agraria: Producción y Sanidad Animal 1:89-111.

Patterson, D. J.; Perry, R. C.; Kirakofe, G. H.; Bellows, R. A.; Staigemiller, R. B. and Corah, L. A. 1992. Management considerations in heifers development and puberty. Journal of Animal Science 70:4018-4035.

Pereira Neto, O. A. and Lobato, J. F. P. 1998. Efeitos da ordem de utilização de pastagens nativas melhoradas no desenvolvimento e desempenho reprodutivo de novilhas de corte. Revista Brasileira de Zootecnia 27:60-65.

Pereira, M. C.; Yokoo, M. J.; Bignardi, A. B.; Sezana, J. C. and Albuquerque, L. G. 2010. Altura da garupa e sua associação com características reprodutivas e de crescimento na raça Nelore. Pesquisa Agropecuária Brasileira 45:613-620.

Pilau, A. and Lobato, J. F. P. 2009. Suplementação energética préacasalamento aos 13/15 meses de idade para novilhas de corte: desenvolvimento e desempenho reprodutivo. Revista Brasileira de Zootecnia 38:2482-2489.

Pilau, A.; Rocha, M. G. and Restle, J. 2005. Desenvolvimento de novilhas de corte recebendo ou não suplementação energética em pastagem com diferentes disponibilidades de forragem. Revista Brasileira de Zootecnia 34:1483-1492.

Pilau, A.; Rocha, M. G. and Restle, J. 2004. Recria de novilhas de corte com diferentes níveis de suplementação energética em pastagem de aveia preta e azevém. Revista Brasileira de Zootecnia 33(supl. 2):2104-2113.

Pötter, B. A. A. and Lobato, J. F. P. 2004. Efeito da carga animal, pastagem melhorada e da idade de desmame no comportamento reprodutivo de vacas primíparas. Revista Brasileira de Zootecnia 33:192-202.

Putney, D. J. 1989. Influence of summer heat stress on pregnancy rates of lactating dairy cattle following embryo transfer or artificial insemination. Theriogenology 31:765-778.

Quadros, S. A. F. and Lobato, J. F. P. 1997. Efeitos da lotação animal na produção de leite de vacas de corte primíparas e no desenvolvimento de seus bezerros. Revista Brasileira de Zootecnia 28:27-33.

Restle, J.; Polli, V. A. and Senna, D. B. 1999. Efeito de grupo genético e heterose sobre a idade e peso a puberdade e sobre o desempenho reprodutivo de novilhas de corte. Pesquisa Agropecuária Brasileira 34:701-707.

Rocha, D. R.; Salles, M. G. F.; Moura, A. A. A. N. and Araujo, A. A. 2012. Impacto do estresse térmico na reprodução da fêmea bovina. Revista Brasileira de Reprodução Animal 36:18-24.

Rocha, M. G. and Lobato, J. F. P. 2002. Sistema de alimentação pós-desmama de bezerras de corte para acasalamento aos 14/15 meses de idade. Revista Brasileira de Zootecnia 31:1814-1822.

Sampedro, D. 2003. Condicion corporal, uma herramienta para planificar el manejo del rodeo de cria. Available at: $<\mathrm{http} / / \mathrm{www}$. inta.gov.ar/mercedes/info/SeriesTecnicas/30/30.html>. Accessed on: Nov. 20, 2009.

Santos, D. T.; Rocha, M. G.; Quadros, F. L. F.; Gento, T. C. M.; Montagner, D. B.; Gonçalves, E. N. and Roman, J. 2005.
Suplementos energéticos para recria de novilhas de corte em pastagens anuais. Desempenho animal. Revista Brasileira de Zootecnia 34:209-219.

Scaglia, G. 1997. Nutriticion y reproduccion de la vaca de cria. Uso de la condición corporal. INIA, Montevidéo. 15p. (Série Técnica 91).

Semmelmann, C. E. N.; Lobato, J. F. P. and Rocha, M. G. 2001. Efeito de sistemas de alimentação no ganho de peso e desempenho reprodutivo de novilhas Nelore acasaladas aos 17-18 meses. Revista Brasileira de Zootecnia 30:835-843.

Short, R. E. and Bellows, R. A. 1971. Relationship among weight gains, age at puberty and reproductive performance in heifers. Journal of Animal Science 32:1964-1970.

Silva, M. D.; Barcellos, J. O. J. and Prates, E. R. 2005. Desempenho reprodutivo de novilhas de corte acasaladas aos 18 ou aos 24 meses de idade. Revista Brasileira de Zootecnia 34:2057-2063.

$\mathrm{t}^{\prime}$ Mannetje, L. 2000. Measuring biomass of grassland. p.151-177. In: Field and laboratory methods for grassland and animal production research. $t^{\prime}$ Mannetje, L. and Jones, R. M., eds. CAB Internacional, Wallingford.

Thatcher, W. W. and Collier, R. J. 1982. Effect of heat on animal productivity. p.77-105. In: CRC Handbook of Agricultural Productivity. CRC Press, Boca Raton.

Thonney, M. L.; Heide, E. K.; Duhaime, D. J.; Nohr, A. Y. M. and Oltenacu, P. A. 1981. Growth and feed efficiency of cattle of different mature sizes. Journal of Animal Science 53:354-362.

Vargas, C. A.; Elzo, M. A.; Chase, C. C.; Chenoweth, P. J. and Olson, T. A. 1998. Estimation of genetics parameters for scrotal circumference, age a puberty in heifers and hip height in Brahman cattle. Journal of Animal Science 76:2536-2541.

Vargas, C. A.; Olson, T. A.; Chase, C. C.; Hammond, A. C. and Elzo, M. A. 1999. Influence of frame size and body condition score on performance of Brahman cattle. Journal of Animal Science 77:3140-3149.

Vaz, R. Z. and Lobato, J. F. P. 2010. Efeito da idade de desmame no desempenho reprodutivo de novilhas de corte expostas à reprodução aos 13/15 meses de idade. Revista Brasileira de Zootecnia 39:142-150.

Vaz, R. Z.; Lobato, J. F. P. and Restle, J. 2010. Influence of weaning age on the reproductive efficiency of primiparous cows. Revista Brasileira de Zootecnia 39:299-307.

Vaz, R. Z.; Restle, J.; Pacheco, P. S.; Vaz, F. N.; Pascoal, L. L. and Vaz, M. B. 2012. Ganho pré e pós-desmame no desempenho reprodutivo de novilhas de corte aos quatorze meses de idade. Ciência Animal Brasileira 13:272-281.

Vieira, A.; Lobato, J. F. P.; Correa, E. S.; Torres Jr., R. A. A. and Costa, F. P. 2006. Desenvolvimento e desempenho reprodutivo de novilhas Nelore criadas a pasto nos cerrados do Centro-Oeste brasileiro. Revista Brasileira de Zootecnia 35:186-192.

Webster, A. J. F. 1989. Bioenergetics, bioengineering and growth. Animal Production 48:249-269.

Wiltbank, J. N.; Robertson, J. N. and Rowden, L. 1985. Reproductive performance and profitability of heifers fed to weight 272 or $318 \mathrm{~kg}$ at the start of the first breeding season. Journal of Animal Science $60: 25-35$. 